\begin{tabular}{|l|l|l||}
\hline \multicolumn{2}{|c|}{ PublisherInfo } \\
\hline \hline PublisherName & $:$ & BioMed Central \\
\hline \hline PublisherLocation & $:$ & London \\
\hline \hline PublisherImprintName & $:$ & BioMed Central \\
\hline \hline
\end{tabular}

\title{
Turning back the clock
}

\begin{tabular}{|l|l|l||}
\hline \multicolumn{2}{|c|}{ ArticleInfo } \\
\hline \hline ArticleID & $:$ & 4710 \\
\hline \hline ArticleDOI & $:$ & $10.1186 /$ gb-spotlight-20030228-01 \\
\hline \hline ArticleCitationID & $:$ & spotlight-20030228-01 \\
\hline \hline ArticleSequenceNumber & $:$ & 62 \\
\hline \hline ArticleCategory & $:$ & Research news \\
\hline ArticleFirstPage & $:$ & 1 \\
\hline \hline ArticleLastPage & $:$ & 2 \\
\hline \hline & & RegistrationDate : 2003-2-28 \\
\hline ArticleHistory & $:$ & OnlineDate \\
\hline \hline ArticleCopyright & $:$ & BioMed Central Ltd2003 \\
\hline \hline ArticleGrants & $:$ & \\
\hline \hline ArticleContext & $:$ & 130594411 \\
\hline \hline
\end{tabular}




\section{Jonathan B Weitzman}

Email: jonathanweitzman@hotmail.com

The relevance and prevalence of antisense and non-coding RNA transcripts in eukaryotes is only now beginning to be appreciated. In the February 27 Nature Kramer et al. report the characterization of an antisense transcript in Neurospora crassa that is a regulator of the circadian clock (Nature 2003, 421:948-952). Cyclic expression of the frequency (frq) gene is important for the rhythmicity of the Neurospora clock. An antisense frq RNA is also ryhthmically produced in the dark and is 180 degrees out of phase with sense frq RNA. The antisense transcript is also induced by light. Disruption of antisense $f r q$ expression led to a delay in the timing of the internal clock and defects in the resetting of the clock. These results offer another example of the regulation of complex biological processes by naturally occurring antisense RNA and highlight the importance of both sense and antisense transcripts in setting the circadian clock.

\section{References}

1. Non-coding RNA genes and the modern RNA world.

2. Nature, [http://www.nature.com]

3. Negative feedback defining a circadian clock: autoregulation of the clock gene frequency. 